
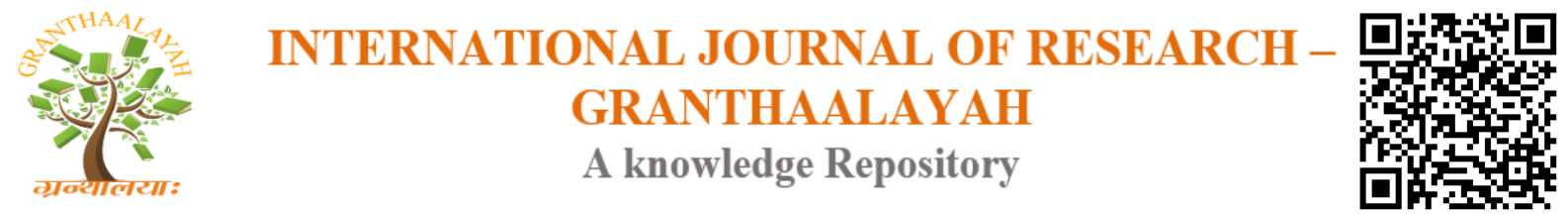

Management

\title{
AGRICULTURAL SEED FINANCING: IMPLICATIONS FOR PRODUCTIVITY AND EXPORT EARNINGS FOR NIGERIA ECONOMY
}

\author{
ZUBERU, O. Emmanuel ${ }^{1}$, ILIYA, Bawa ${ }^{2}$, YUSUF, Salamatu ${ }^{3}$, SALIHU, O Ramat ${ }^{4}$ \\ ${ }^{1}$ Department of Business Administration, Federal Polytechnic, Nasarawa, Nigeria \\ ${ }^{2}$ Department of Marketing, Federal Polytechnic Nasarawa, Nigeria \\ ${ }^{3}$ Departments of Education, Nasarawa Local Government Authority, Nasarawa State, Nigeria \\ ${ }^{4}$ Federal Polytechnic Staff School, Nasarawa, Nigeria
}

\begin{abstract}
Since the discovery of oil, there has been a drastic decline in agricultural exports as percentage of total exports declined from about $43 \%$ to slightly over 7\% between 1970 and 1974, as a result of the oil price shocks of $1973-1974$ which resulted in large receipts of foreign exchange earnings by Nigeria and the neglect of agriculture. There have been series of declines in agricultural export since the mid-1970s at an average annual decline rate of 17 percent and by 1996, agricultural export accounted for only 2 percent of total exports, hence, making Nigeria net importer of basic food stuff. With this continual decline, the agricultural sector no longer earns enough foreign exchange through exports. Hence, this study investigates implications of agricultural seed financing on increased productivity output and export earnings in Nigeria. The choice of research design employed in this study is the archival and documentary research strategy, associated with the deductive approach, which involved secondary data collection. The population comprised 16 years data on total annual financial expenditure on agricultural seed improvement, agricultural productivity output and export earnings from 2000 to 2015 (16 years). Secondary data on cumulative annual expenditure on seed financing (SIF), Agricultural productivity (AP) indicator and export earnings (EE) were employed. The findings revealed that, findings revealed that Seed improvement financing has a significant impact on increased Agricultural production output and that there is a significant relationship between Agricultural production output and increased export earnings in Nigeria. The study therefore recommended that, there is need for the government to increase funding for agricultural research and also access international grants, as this will help increase variety of high yield seeds and subsequently increase agricultural production output, which will increase agro related export earnings in Nigeria.
\end{abstract}

Keywords: Agriculture; Seed Financing; Export Earnings; Productivity; Output.

Cite This Article: ZUBERU, O. Emmanuel, ILIYA, Bawa, YUSUF, Salamatu, SALIHU, And O Ramat. (2017). "AGRICULTURAL SEED FINANCING: IMPLICATIONS FOR PRODUCTIVITY AND EXPORT EARNINGS FOR NIGERIA ECONOMY." International Journal of Research - Granthaalayah, 5(10), 228-245. 


\section{Introduction}

The conventional roles of agriculture in a developing and growing economy involves supply of economic surplus that can be consumed or utilized for further production in agriculture or transferred to provide capital for industrial growth; to meet expanding consumption needs of the urban population; make possible the release of labour and other resources for use in the nonagricultural sectors; to increase the purchasing power of rural people, expand markets for industrial goods and help bring about needed changes in national economies and earn foreign exchange through commodity exports (Abayomi, 1997). Added to the above is the stimulation of the development of other complementary sectors of the economy, like the chemical industry which takes care of pesticides and fertilizers; the iron and steel/engineering industries which takes care of the agricultural tools and implements (Dowrick \& Gemmell, 1991). Thus agriculture is the bedrock and backbone of any economy, while in Nigeria; agriculture remains the most important sector of the economy.

Agriculture has remained the most crucial sector of the Nigeria economy upon which nearly all other sectors are dependent upon for growth and development. Prior to and immediately after the attainment of Independence in 1960, agriculture was the country's major income earner accounting for more than 70 percent of the gross domestic products (Odozi, 1995). Though the contribution of the sector to the Nigerian economy has been described as enormous in terms of supply of adequate raw materials to a growing industrial sector (Okumadawa, 1997); a major source of employment generation, foreign exchange earnings; provision of a market for the products of the industrial sector (World Bank, 1998); and provision of food for the increasing population (Food Agricultural Organization, 2006); however, agricultural production in Nigeria is progressively on the decline in terms of its annual contribution to the Gross Domestic Product.

There is a growing recognition by the Nigerian government of the significance and multiplier effects of improved inputs and new technologies on agricultural yield. The use of these inputs and the adoption of high yielding techniques have given rise to an increased need for agricultural financing, since majority of Nigerian farmers are small-scale farmers and are often limited by unfavourable economic, social, cultural and institutional conditions (Olubiyo \& Hill, 2000). Insufficiency of capital has been a major constraint to agricultural development (Agu, 1998), in order to improve agricultural production, modern farm inputs such as fertilizers, improved seeds, feeds, plant protection chemicals and agricultural machineries are needed over the hoe and machete technology. Most of these technologies have to be purchased, yet very few farmers have the financial resources to finance such capital intensive purchases (Adeniji \& Joshua, 2008).

Agricultural development involves three approaches namely bio-chemical, socio-economic and engineering known as the trio of technologies (Mrema and Odigboh, 1993). The biochemical approach according to Asoegwu and Asoegwu, (2007), includes the development of improved animal and plant species, animal and plant nutrients (fertilizer and feed) and plant and animal protection (veterinary drugs, pesticides and herbicides). The socio-economic approach includes financial packages and management programmes (Mrema \& Odigboh, 1993; Asoegwu \& Asoegwu, 2007). The engineering approach deals with the provision of agricultural machines and equipment (Ani \& Onwualu, 2002) for production and post-harvest systems, handling and storage systems and farm structures, erosion control measures, water resources development as well as irrigation and drainage structures, meteorological systems (Ampratwum et al., 2004), and 
the technologies for optimally utilizing the above and their proper and economic use and management (Onwualu \& Pawa, 2004; Asoegwu \& Asoegwu, 2007).

In an effort to diversify her oil based economy, the Federal Government of Nigeria is placing much emphasis on financing other sectors most especially the agricultural sector, since agriculture has the potentials of stimulating economic growth through provision of raw materials, food, jobs and increased financial stability. It follows that agriculture financing is one of the most important instruments of economic policy for Nigeria, in her effort to stimulate development in all directions (Obansa \& Maduekwe, 2013). Finance, according to Adesoye, et al. (2011) is required in the agricultural sector to purchase land, construct buildings, acquire machinery and equipment, hire labour, irrigation etc. In certain cases such loans may also be needed to purchase new and appropriate technologies. Not only can finance remove financial constraints, but it may also accelerate the adoption of new technologies

Scholarly research on agricultural credits and financing abound (Izekor \& Alufohai, 2010; Zhang, 2010; Obansa \& Maduekwe, 2013) and many others, however, both extant and recent studies in agricultural financing in Nigeria have not focused at the triple causal relationship between agricultural financing (seed improvement, equipment and value chain financing) and productivity (output, technological advancement and food security) in Nigeria, linking both to economic growth (employment, export earnings, increased revenue). Considering the pivotal place of agriculture in both the GDP and employment generation in Nigeria, coupled with the fact that the government has been expending much resource to grow the sector, the researcher opines that it makes research sense to evaluate the causal relationship between agricultural financing, productivity and economic growth in Nigeria, which forms the gap and hence, thrust of this study.

From the standpoint of contribution to economic growth, agriculture was the leading sector contributing about $70 \%$ of the Gross Domestic Product (GDP), employing about the same percentage of the working population and accounting for about $90 \%$ of foreign earnings and Federal Government revenue (Gbaiye, Ogundipe, Osabuohien \& Olugbire, 2013). During this period, Gbaiye, et al. (2013) asserts that, Nigeria was the world's second largest producer of cocoa, largest exporter and producer of palm products. Nigeria was also a major exporter of leading commodities such as cotton, groundnut, rubber, hides and skins (Alkali, 1997).

\section{Statement of the Problem}

Since the discovery of oil, there has been a drastic decline in agricultural exports as percentage of total exports declined from about $43 \%$ to slightly over $7 \%$ between 1970 and 1974, as a result of the oil price shocks of 1973 - 1974 which resulted in large receipts of foreign exchange earnings by Nigeria and the neglect of agriculture (Gbaiye, et al., 2013). There have been series of further declines from the mid-1970s at an average annual growth rate declined by 17 percent and by 1996, agricultural export accounted for only 2 percent of total exports, hence, making Nigeria net importer of basic food stuff (Bakare \& Fawehinmi, 2011). With this continual decline, the agricultural sector no longer meets domestic food requirements, supply raw materials for industry and earn enough foreign exchange through exports. Food production has since 
become a major problem in Nigeria and huge foreign exchange earnings are being utilized in importing food.

Based on the above stated problems, all efforts put in place over the years to achieve increased productivity output through the agricultural financing have not yielded expected results. Hence, the broad objective of this study investigates implications of agricultural seed financing on increased productivity output and export earnings in Nigeria. The specific objectives this study aims to achieve are;

1) Determine the impact of seed improvement financing on increased Agricultural productivity output in Nigeria.

2) Examine the relationship between Agricultural productivity output and increased export earnings in Nigeria.

Based on the broad and specific objectives of this study, the following null hypotheses are posited for testing and conclusion to be inferred in order to achieve the research objectives;

$\mathbf{H}_{\mathbf{0 1}}$ : Seed improvement financing has no significant impact on increased Agricultural productivity output in Nigeria

$\mathbf{H}_{\text {02 }}$ : There is no significant relationship between Agricultural productivity output and increased export earnings in Nigeria

\section{Literature Review}

Agriculture has been defined as the production of food and livestock and the purposeful tendering of plants and animals, (Ahmed, 1993). He stated further that agriculture is the mainstay of many economies and it is fundamental to the socio-economic development of a nation because it is a major element and factor in national development. In the same view, Okolo (2004), describe agricultural sector as the most important sector of the economy which holds a lot of potentials for the future economic development of the nation as it had done in the past.

Before the discovery of oil in Nigeria, agriculture accounted for over $60 \%$ of its Gross Domestic Product (GDP) as well as being a major source of foreign exchange earnings. It provided food and employment for the teeming population and raw materials for the growing industries. Nigerian economy, like that of Brazil, could reasonably be described as an agricultural economy during the first decade after independence. This is because agriculture served as the engine of growth of the overall economy of the two countries. During the period of 1960s, Nigeria was the world's second largest producer of cocoa, the largest exporter of palm kernel and the largest producer and exporter of palm oil. It was also a leading exporter of other major commodities such as cotton, groundnut, rubber, as well as hides and skins (Alkali, 1997; Lawal, 1997).

During the period of 1960s, Nigeria was the world's second largest producer of cocoa, the largest exporter of palm kernel and the largest producer and exporter of palm oil. It was also a leading exporter of other major commodities such as cotton, groundnut, rubber, as well as hides and skins (Alkali, 1997; Lawal, 1997). Despite the reliance of Nigerian peasant farmers on traditional tools and indigenous farming methods, these farmers produced $70 \%$ of Nigeria's exports and $95 \%$ of its food needs. The agricultural sector however suffered neglect during the hey-days of 
the oil boom in the 1970s. Ogen (2007) stated that agricultural sector accounted for less than 5\% of Nigeria's GDP in 2004. Ever since then, Nigeria has been facing serious poverty challenges and the insufficiency of basic food needs (NEEDS, 2004). It is further revealed by the NEEDS Policy Paper, 2004 that it is estimated that two-thirds of Nigerians live below the poverty line of US $\$ 1$ per day, most of them in the rural areas. The root of this crisis lies in the neglect of agriculture and the increased dependency on monocultural economy based on oil.

\section{Agricultural Finance}

The role of financial capital as a factor of production to facilitate economic growth and development as well as the need to appropriately channel credit to rural areas for economic development of the poor rural farmers cannot be over emphasized. As Rahji (2008) put it, finance (capital) is viewed as more than just another resource such as labour, land, equipment and raw materials. In the same way, Shepherd (2007) stated that finance determines access to all of the resources on which farmers depend. Consequently, provision of appropriate macroeconomic policies and enabling institutional finance for agricultural development is capable of facilitating agricultural development with a view to enhancing the contribution of the sector in the generation of employment, income and foreign exchange (Olomola, 1997). Also, higher level of investment (gross capital formation) should stimulate growth while agricultural productivity is expected to have a positive effect on aggregate economic growth.

Finance for agricultural development has an increasing role in contemporary times. According to Nzotta and Okereke (2009), finance affects economic growth, stagnation or even decline in any economic system. The Nigerian government recognises that finance is an essential tool for promoting agricultural development because the agriculture sector is one of its main sources of sustainability. Access to finance for agriculture is an incentive for increasing the agricultural sector's performance; it stimulates productive growth, and supports the survival of small and new enterprises. Adams and Mortimore (1997) noted that access to finance increases the average inputs of labour and capital which has positive effects on productivity output. Irrespective of the benefits that can be derived from financing agriculture, there is an inherent risk of loan defaults amongst farmers, which discourages banks from lending to farmers.

Agricultural finance can be defined as the mobilisation of resources at all levels in order to increase production and productivity in agriculture and to enhance the productive capacity (Ayeomoni \& Aladejana, 2016). Agriculture finance in an emerging world could have positive effects on the growth of gross domestic products, which translates to the entire economy's wellbeing. Agriculture finance brings about growth and it solves the problems militating against the agriculture sector's productivity. It plays the role of an effective engine for growth for most agriculture-based countries (ADB, 2000). Also at the instance of high population growth rates, there is a pressure on low input/ output agricultural systems to accelerate increase in food production through finance (Ayeomoni \& Aladejana, 2016). Estimates show that GDP growth originating in agriculture is at least twice as effective in reducing poverty as GDP growth originating outside agriculture (WDR, 2008). 


\section{Agricultural Seed Improvement and Finance}

Kormawa Okorji and Okechukwu, (2013) describes seed improvement as high yield variety (HYV) Agricultural inputs with the following characteristics; which includes (a) the seeds must be genetically pure, representing the species or cultivars in question, morphologically well developed, undamaged and exhibiting characteristics typical of the variety, (b) cleaned, sometimes graded, and then tested for purity and germination capacity, and (c) free from pests and diseases (Muliokela \& Kaliangile, 1989). Thus, seed improvement encompasses scientifically and technologically quality certified seeds for improved productivity and food security.

Technology is assumed to mean a new, scientifically derived, often complex input supplied to farmers by organizations with deep technical expertise. Neill and Lee (2001) point out that the majority of existing literature on agricultural technology adoption is focused on Green Revolution (GR) technologies such as patterns of high-yield variety (seed improvement) irrigation and fertilizer use. Isa (2015) asserts that, due to the development process of improved Agricultural seeds and the inputs required to make them productive, studies examining improved Agricultural seeds adoption look at very advanced forms of technology; improved Agricultural seeds are often the product of intensive laboratory research, and when they are targeted to farmers they are bundled with other technology inputs such as chemical fertilizers, pesticides and extensive irrigation because these are necessary for the improved Agricultural seeds to perform as designed (Bello, Ganiyu, Wahab, Afolabi, Oluleye, Ig, Mahmud, Azeez \& Abdulmaliq, 2012).

The Nigerian agricultural seed sector has evolved over the last 30 years in terms of seed science and commercial seed production capabilities. However, the sector is still under-performing in terms of meeting the agricultural seed needs of the country. Consequently, the government of Nigeria imported rice seeds in 2012, while vegetable seeds are still mostly imported through informal channels (WAAPP, 2012). The development and performance of the seed sector is constrained by many factors which include weak technical capacity, poor market mechanisms, and inefficient enforcement of seed law, information asymmetry, insufficient capital investment and low utilization of innovations. These and other constraints have been tabulated in this section and appropriate solutions recommended for each constraint. In general the challenges facing the seed sector are complex and require comprehensive strategic solutions (Kormawa Okorji \& Okechukwu, 2013).

One of the government interventions into the agricultural sector was the supply of improved seedlings at zero cost (subsidy) to the farmers. This aims at increasing the accessibility of farmers to large quantity of seedlings to enhance their production capacity (Alamu, 2013). The financing of improved seedlings was based on the fact that supply of adequate quantity of improved seedlings constitutes a catalyst for agricultural development, foundation for crop production and productivity and realisation of agricultural transformation agenda in the country. The focus of the seed improvement financing is to rehabilitate the old plantations and establishment of new farms with improved seedlings to enhance increase in agricultural production in the country (Tiba, 2009; Alamu. 2013). 


\section{Empirical Review}

Alamu, (2013) in a study analysed seedling subsidy policy and cocoa production in south-west Nigeria. Data were collected with questionnaires and interviews. Purposive sampling technique was used in the selection of Key Informants on cocoa production. Descriptive statistics and content analytical techniques were used for analysing the collected data. Findings showed that $79 \%, 95 \%$ and $96 \%$ of local government areas in Oyo, Ondo and Osun States respectively are producing cocoa. Again, both Ondo and Oyo states have been supplying more than one million seedlings while Osun has been supplying 800,000 seedlings to their farmers every year since the commencement of seedling subsidy policy. The unit cost of the seedlings was between N10 and N20 in Ondo and Osun states respectively due to 50\% subsidy while Oyo state was supplying the seedlings at $100 \%$ subsidy to the farmers. Ondo state produced the highest quantity of cocoa in 2005, 2006, 2009 and 2011 while Osun recorded highest production figure in 2007 and 2008. Inadequate funding, delay in release of funds and dearth of manpower are the major challenges to its implementation. The study recommends adequate and timely release of funds for seedling production and provision of $100 \%$ subsidy to enhance cocoa production in the country.

Akpan, Okon and Udoka, (2014) in their study, established empirical relationships between remittances (foreign exchange earnings) and indicators of agricultural productivity (agricultural GDP/total GDP, Agricultural productivity index and crop productivity index) in Nigeria. Augmented Dickey-Fuller unit root tests were conducted on the specified time series to ascertain the variables' order of integration. The trend analysis revealed that, remittances (foreign exchange earnings), agricultural GDP, agricultural productivity index and crop productivity index have positive exponential growth rates, but remittances (foreign exchange earnings) grew at a faster rate than others. It was discovered that, remittance (foreign exchange earnings) has linear and symmetric relationships with agricultural productivity index and crop productivity index in Nigeria. However, there was no significant relationship among growth rates of remittances, agricultural GDP, agricultural productivity index and crop productivity index in Nigeria. The bilateral Granger causality test indicates unilateral relationship between nominal value of agricultural GDP and remittance inflow in the country. The result of the co-integration test revealed the presence of co-integration among specified variables. Agricultural productivity index and crop productivity index have significant relationships with remittance in the long run. Also, agricultural GDP and agricultural productivity index exhibited significant association with remittances in the short run.

Uremadu and Onyele, (2016) analyzed the impact of selected agricultural exports on economic growth in Nigeria from 1980 to 2014. They specifically examined the determinants of total agricultural export supply, cocoa export supply and rubber export supply; their export performance and determining factors. Both export crops were chosen because they remain the most exported agricultural commodities from Nigeria, and published national aggregates on specific trade and macroeconomic variables in CBN Statistical Bulletin (various years) and National Bureau of Statistics (NBS). For the data analysis, descriptive statistic and ordinary least square (OLS) were used. The results revealed that export supply of cocoa was insignificant, but had a positive impact on real GDP, while the coefficient of export supply of rubber was negative and insignificant at 5\% level. Export commodity price index was found to be significant with a positive impact on real GDP, depicting that export commodity prices have been favourable 
during the period under study. Domestic economic growth (proxied by real GDP) was influenced positively by exchange rate, interest rate, and trade openness, but only exchange rate was significant, while inflation rate had a negative impact on economic growth. The results further showed that the aggregate agricultural exports was positive and had a significant impact on economic growth in Nigeria. The study therefore recommended policy options such as export financing, value addition to cocoa beans being exported, and favourable foreign exchange policies to promote production in the export subsector of agriculture and industrial sector for proper diversification of Nigerian economy in the years ahead.

Oluwaseun, et al., (2013) investigated Agricultural Exports and Economic Growth in Nigeria (1980 - 2010), focusing on determining if a significant long-run relationship exists between agricultural exports and economic growth in the present-day Nigeria. the study also assessed the long run impact of agricultural exports on growth performance in Nigeria. The underlying models employed by the study are the Export- Led Growth Hypothesis and the Neo-classical Growth Model. In the formulated model, Real Gross Domestic Product was used as the proxy for economic growth. The explanatory variables used were Gross Fixed Capital Formation, Labour force, Foreign Direct Investment and Agricultural exports. The study made use of unit root tests and Johansen Maximum Likelihood Test of Co-Integration. It was discovered that a long run equilibrium relationship exists between agricultural exports and economic growth and the relationship is elastic in nature meaning that a unit increase in agricultural exports would bring a more than proportionate increase in the Real Gross Domestic Product in Nigeria.

\section{François Quesnay (1694-1774) Theory of Economic Growth}

The physiocrats laid more emphasis on agriculture in the development of an economy. In their views, the source of national wealth is essentially agriculture. The agricultural sector to the physiocrats is the only genuinely productive sector of the economy and generator of surplus upon which all depends. Todaro and Smith (2003), while looking at the Lewis theory of development, assumed that underdeveloped economies consist of two sectors. These sectors consist of traditional agricultural sector and the modern industrial sector. Agricultural development was seen as necessary for successful economic transformation.

According to the export-led growth literature, exports growth is a measure of outward orientation and could also serve as a proxy for internationally competitive cost structure. Export expansion can be a catalyst for output growth both directly, as a component of aggregate output, as well as indirectly through efficient resource allocation, greater capacity utilization, exploitation of economies of scale and stimulation of technological improvement due to foreign market competition (Fischer \& Witt, 1994 in Uremadu \& Onyele, 2016).

Also, higher level of investment (gross capital formation) should stimulate growth while agricultural productivity is expected to have a positive effect on aggregate economic growth. It has been observed by Subasat (2002), that countries at the early stages of development depend almost fully on agricultural growth for employment, foreign exchange, government revenue and food supply to the population. In this sense, agricultural growth is the key impetus to the growth of underdeveloped and developing countries (Uremadu \& Onyele, 2016). 
The Physiocracy is based on one core proposition; the agricultural sector is the only sector capable of generating a net surplus, which is paid as a rent or revenue to the landlords, while the industrial sector remains sterile because it cannot produce profits. Quesnay thought that the industrial sector would always have a rate of return of zero, the manufacturing sector would not produce surplus over cost. The reason was that competition among entrepreneurs would prevent them from generating a surplus over cost. An increase in industrial efficiency would just cheapen products and not produce a surplus for the producers. On the other hand, an increase in agricultural efficiency would increase the surplus of the economy.

Quesnay thought that agricultural costs were fixed. He identified these costs as the food that the farmers would consume themselves while producing. Since the food consumed by the farmers is constant; an increase in the nation's farms productivity would suppose an increase of the nation's surplus. That is why he thought that farmers should not be taxed in order to allow them to increase the capital/labour ratio. The capital/labour intensity of agriculture determined the size of this surplus. Landlords would have higher revenues, and would increase the demand of finished products. Because of this, artisans would be able to subsist. Consequently the surplus in agriculture would cover the cost of the raw materials of producing manufactures, the expenses incurred by the workers, and the merchant's return. His opinion was that the manufacturing sector can only exist through the wealth of those who pay for it - the landowners. Moreover, he expressed that manufacturing sector was dependent on the agriculture, since this was the origin of the raw materials used to produce manufactures.

One of the failures of the Physiocrats was that they did not realize that in their times, there were already prosperous capitalism, bankers and merchants. This is one of the main weaknesses of the theory; the absence of entrepreneur's profit. When asked about the existence of great merchants, his answer was that in a perfect competition market these great merchants would not exist. It seems that Quesnay's was simplifying his model making the assumption that entrepreneurs would have a constant returns over time, enough to keep the incentives to operate such activity, but not enough to generate profits, since an increase of capital would not mean higher income, but lower prices (Taylor, 1960).

Quesnay believed that the net surplus generated by the agricultural sector was determining the aggregate demand of the economy. To distribute the wealth to the whole nation, this surplus or circulating capital should be spent in its totality by the landowners, and nothing should held back or lost overseas. According to Quesnay theories, the economic flow was as follows. Farmers would produce the nation's net surplus. Then, a small part of it would be destined for own consumption and replacement of working capital, and in exchange of money used to buy urban products. The rest would be used to pay the landowners, who after using part of it in their own consumption; would be in possession of the country's net income. After paying taxes these landlords would be contributing to the country's stock of wealth (Blaug, 1962). The agricultural sector would generate income to the tenants every year and still reserve income - circulating capital or "annual advances" - as advances for the following year. The sterile sector would receive a part, and half of it would be spent on food. The remaining will be used for the reposition of raw materials and other expenses that would allow the constant output in this sector of the economy. 


\section{Research Methodology}

The choice of research design employed in this study is the archival and documentary research strategy, associated with the deductive approach, used for descriptive research purpose (Saunders, et al., 2009); the rationale is to allow collection of quantitative. Furthermore, the research choice employed is the quantitative method, which involves secondary data collection technique. In the area of research design, the study used mathematical (econometric) models in the analysis. It is also designed to be inductive in nature, since the researcher will be drawing conclusions based on the analysis of the data collected.

The population of this study comprises 16 years data on total annual financial expenditure on agricultural equipment, agricultural productivity output and export earnings from 2000 to 2015 (16 years) forms the population of the study. Data for this period is to have a considerable degree of freedom that will be necessary to capture the net effect of the explanatory variables on the dependent variables. Secondary data on cumulative annual expenditure on seed financing (SIF), Agricultural productivity indicator and export earnings (EE) were sourced from the CBN annual report, statement of account and statistical bulletins, World Bank report, Federal Ministry of Agriculture and the National Bureau of Statistics, in line with the time series based multiple source, secondary data method of data collection.

\section{Data Analysis and Model Specification}

Data collected was analysed using time series data analysis and graphs, while postulated hypotheses were tested using student F-statistics. The decision rule for accepting or rejecting the null hypothesis for any of these tests will be based on the Probability Value (PV). If the PV is less than $5 \%$ or 0.05 (that is PV < 0.05), it implies that the regressor in question is statistically significant at 5\% level; otherwise, it is not significant at that level. The model is functionally specified below is specified to analyse the two hypotheses:

$A P=f(S I F)$

$E E=f(A P)$

The study shall conduct unit root tests using Augmented Dickey-Fuller (ADF) to ascertain the stationarity of the data before carrying out the cointegration test. After establishing the existence of long-run cointegration relationship, the study will investigate both the long-run effects and the short-run dynamics using the Error Correction Model (ECM) approach. Banerjee, et. al (1998) stated that a dynamic Error Correction Model (ECM) can be derived through a simple linear transformation. ECM gives the short run coefficient without losing the long run information. The lag length or order of the variables will be selected by using Akaike Information Criteria (AIC). The choice of AIC is that it gives the heaviest penalties for loss of degree of freedom and also imposes a larger penalty for additional coefficients (Ogwumike \& Ofoegbu, 2012). The ECM model provided by Pesaran, Shin and Smith (2001) is given as:

$$
\Delta Y_{t}=\alpha_{0}+\alpha_{1} Y_{t-1}+\alpha_{2} X_{t-1}+\sum_{i=1}^{i} \beta_{1 i} \Delta Y_{t-i}+\sum_{i=0}^{j} \beta_{2 i} \Delta X_{t-i}+\varepsilon_{t}
$$


Therefore, linearizing equation (1 to 2 ), so as to obtain a steady state Error Correction Model (ECM), we have:

$$
\begin{aligned}
& \Delta A P_{t}=\beta_{0}+\sum_{i=1}^{q} \beta_{5}^{i} \Delta A P_{t-i}+\sum_{j=0}^{r} \beta_{6}^{i} \Delta S I F_{t-j}+\delta E C T+\varepsilon_{t} \\
& \Delta E E_{t}=\beta_{0}+\sum_{i=1}^{s} \beta_{7}^{i} \Delta E E_{t-i}+\sum_{j=0}^{t} \beta_{8}^{i} \Delta A P_{t-j}+\delta E C T+\varepsilon_{t}
\end{aligned}
$$

Where;

$\begin{array}{lll}\mathrm{AP} & = & \text { Agricultural productivity (outputs) } \\ \mathrm{SIF} & = & \text { Seed Improvement Financing } \\ \mathrm{EE} & = & \text { Export Earnings } \\ \beta_{0} & = & \text { the autonomous parameter estimate (Intercept or constant) } \\ \beta_{1} \text { to } \beta_{12} & = & \text { Parameter coefficients } \\ \Delta & = & \text { First difference operator } \\ \varepsilon_{t} & = & \text { The white noise error term } \\ \mathrm{ECT} & = & \text { The error correction term } \\ \delta & = & \text { The speed of adjustment parameter }\end{array}$

\section{Results and Discussions}

The two hypotheses formulated in this study were tested using the F-statistics. The F-statistics is a test of the overall significance of the entire variables used in the regression model; it is used to denote whether the joint impact of the explanatory (exogenous/ independent variables) actually have a significant influence on the dependent variable. The decision rule for accepting or rejecting the null hypothesis for any of these tests will be based on the Probability Value (PV). If the PV is less than $5 \%$ or 0.05 (that is $\mathrm{PV}<0.05$ ), it implies that the regressor in question is statistically significant at 5\% level; otherwise, it is not significant at that level. The null hypothesis is stated against the alternative hypothesis as:

\section{Test of Hypotheses One}

\section{$H_{01}: \quad$ Seed improvement financing has no significant impact on increased Agricultural Production output in Nigeria}

Table 1: Regression Result on Seed improvement financing and Agricultural production output Dependent Variable: AP

Method: ARDL

Date: 06/22/17 Time: 23:44

Sample (adjusted): 20022015

Included observations: 14 after adjustments

Maximum dependent lags: 1 (Automatic selection)

Model selection method: Akaike info criterion (AIC)

Dynamic regressors (3 lags, automatic): SIF

Fixed regressors: $\mathrm{C}$

Number of models evaluated: 4

Selected Model: ARDL $(1,2)$

Note: final equation sample is larger than selection sample 


\begin{tabular}{|c|c|c|c|c|}
\hline Variable & Coefficient & Std. Error & t-Statistic & Prob.* \\
\hline $\mathrm{AP}(-1)$ & 0.458828 & 0.128356 & 3.574650 & 0.0060 \\
\hline SIF & 21.88787 & 35.88812 & 0.609892 & 0.5570 \\
\hline $\operatorname{SIF}(-1)$ & 13.39116 & 57.16326 & 0.234262 & 0.8200 \\
\hline $\operatorname{SIF}(-2)$ & -17.02369 & 46.39123 & -0.366959 & 0.7221 \\
\hline CointEq(-1) & -0.541172 & 0.128356 & -4.216171 & 0.0023 \\
\hline $\mathrm{C}$ & 2117.358 & 402.8437 & 5.256029 & 0.0005 \\
\hline R-squared & 0.988338 & \multicolumn{2}{|c|}{ Mean dependent var } & 11902.52 \\
\hline Adjusted R-squared & 0.983154 & \multicolumn{2}{|c|}{ S.D. dependent var } & 2690.254 \\
\hline S.E. of regression & 349.1718 & \multicolumn{2}{|c|}{ Akaike info criterion } & 14.82146 \\
\hline Sum squared resid & 1097289. & \multicolumn{2}{|c|}{ Schwarz criterion } & 15.04969 \\
\hline Log likelihood & -98.75021 & \multicolumn{2}{|c|}{ Hannan-Quinn criter. } & 14.80033 \\
\hline F-statistic & 9.886763 & \multicolumn{2}{|c|}{ Durbin-Watson stat } & 1.805165 \\
\hline $\operatorname{Prob}($ F-statistic) & 0.024151 & & & \\
\hline
\end{tabular}

*Note: p-values and any subsequent tests do not account for model selection.

Source: Authors Computation, 2017 (Eview-9.0)

\section{The F-statistic: Test of Hypothesis Three}

From Table 1, it could be observed that overall regression model is also significant. This was captured by the probability F-statistic value of 0.024 is also less than 0.05 . Thus, we may conclude Seed improvement financing has a significant impact on increased Agricultural production output in Nigeria.

\section{The $R^{2}$ (R-square)}

More so, the $R^{2}$ (R-square) value of 0.9883 shows that the model have a very good fit also. It showed that about 98.83 percent of the variation in Agricultural production output is explained by Seed improvement financing, while the remaining 1.17 percentage unaccounted variation is captured by the error term. It showed that Seed improvement financing had strong significant impact on Agricultural production output.

\section{Post- Estimation Diagnostics Tests}

\section{Serial correlation}

Serial LM test: More so, the regression model is free of serial correlation going by the result of the serial LM test.

Table 2: Breusch-Godfrey Serial Correlation LM Test

\begin{tabular}{llll}
\hline \hline F-statistic & 0.421146 & Prob. F(2,21) & 0.4423 \\
Obs*R-squared & 1.829466 & Prob. Chi-Square(2) & 0.3456 \\
\hline \hline
\end{tabular}

Source: Authors Computation, 2017 (Eview-9.0) 
From table 2 the Prob. Chi-square gave 0.4423, and it's greater than 0.05; thus we accept the null hypothesis that there is no serial correlation among the variables used in the model.

Durbin Watson (DW) statistics which is also used to test for the presence of serial correlation indicates that there is no autocorrelation among the variables as captured by (DW) statistic of 1.80 , and as thus the estimates are unbiased and can further be relied upon for sound policy decisions.

\section{Heteroscedasticity Test}

The regression model is homoscedastic as shown in table 3 below:

Table 3: Heteroskedasticity Test- Breusch-Pagan-Godfrey

\begin{tabular}{llll}
\hline \hline F-statistic & 0.340349 & Prob. F(3,23) & 0.5114 \\
Obs*R-squared & 0.871353 & Prob. Chi-Square(3) & 0.9675 \\
Scaled explained SS & 0.106138 & Prob. Chi-Square(3) & 0.9911 \\
\hline \hline
\end{tabular}

Source: Authors Computation, 2017 (Eview-9.0)

From table 3, the Prob. F-value gave 0.5441, and it's greater than 0.05 ; thus we accept the null hypothesis that there is no heteroscedsticity among the variables used in the model

\section{Test of Hypotheses Two:}

\section{$H_{02}$ : There is no significant relationship between Agricultural production output and increased export earnings in Nigeria}

Table 4: Regression Result on Agricultural production output and export earnings

Dependent Variable: EE

Method: ARDL

Date: 06/22/17 Time: 23:46

Sample (adjusted): 20022015

Included observations: 14 after adjustments

Maximum dependent lags: 1 (Automatic selection)

Model selection method: Akaike info criterion (AIC)

Dynamic regressors (4 lags, automatic): AP

Fixed regressors: $\mathrm{C}$

Number of models evaluated: 5

Selected Model: ARDL $(1,2)$

Note: final equation sample is larger than selection sample

\begin{tabular}{lcccc}
\hline \hline Variable & Coefficient & Std. Error & t-Statistic & Prob.* \\
\hline \hline EE(-1) & 0.463639 & 0.426768 & 1.086394 & 0.3055 \\
AP & 0.084182 & 0.164186 & 0.512723 & 0.6205 \\
AP(-1) & 0.003702 & 0.102943 & 0.035960 & 0.9721 \\
AP(-2) & -0.022454 & 0.101625 & -0.220954 & 0.8301 \\
CointEq(-- & & & & \\
$1) \quad 0.5363610 .4267681 .2567970 .2405-0.536361$ & 0.426768 & -1.256797 & 0.2405 \\
& & & & \\
\hline
\end{tabular}




\begin{tabular}{|c|c|c|c|}
\hline $\mathrm{C}$ & -520.5494 & -0.699450 & 0.5019 \\
\hline R-squared & 0.844753 & Mean dependent var & 501.1805 \\
\hline Adjusted R-squared & 0.775754 & S.D. dependent var & 376.8907 \\
\hline S.E. of regression & 178.4753 & Akaike info criterion & 13.47923 \\
\hline Sum squared resid & 286680.8 & Schwarz criterion & 13.70747 \\
\hline Log likelihood & -89.35461 & Hannan-Quinn criter. & 13.45810 \\
\hline F-statistic & 12.24299 & Durbin-Watson stat & 1.777584 \\
\hline Prob(F-statistic) & 0.001099 & & \\
\hline
\end{tabular}

*Note: p-values and any subsequent tests do not account for model selection

Source: Authors Computation, 2017 (Eview-9.0)

\section{The F-statistic: Test of Hypothesis Four}

Also, by examining the overall fit and significance of the export earnings model, it was found to have a good fit, as indicated by the high $F$-statistic value of 12.24 and it is significant at the 5.0 per cent level. That is, the F-statistic p-value of 0.001 is less than 0.05 . Thus, we will conclude there is a significant relationship between Agricultural production output and increased export earnings in Nigeria.

\section{The $R^{2}$ (R-square)}

The $R^{2}$ (R-square) value of 0.8447 shows that the model have a very good fit also. It showed that about 84.47 percent of the variation in Agricultural production output is explained by export earnings in Nigeria, while the remaining 15.53 percentage unaccounted variation is captured by the error term. It showed that agricultural production output had strong significant impact on export earnings in Nigeria.

\section{Post- Estimation Diagnostics Tests}

\section{Serial correlation}

Serial LM test: More so, the regression model is free of serial correlation going by the result of the serial LM test.

Table 5: Breusch-Godfrey Serial Correlation LM Test

\begin{tabular}{llll}
\hline \hline F-statistic & 0.763170 & Prob. F(2,21) & 0.4891 \\
Obs*R-squared & 1.829466 & Prob. Chi-Square(2) & 0.0006 \\
\hline \hline
\end{tabular}

From table 5 the Prob. Chi-square gave 0.4891, and it's greater than 0.05; thus, we accept the null hypothesis that there is no serial correlation among the variables used in the model.

Durbin Watson $(D W)$ statistic was also used to test for the presence of serial correlation or autocorrelation among the error terms. 
The model also indicates the alternative hypothesis $\left(\mathrm{H}_{1}\right)$ is accepted, indicating that there is no autocorrelation among the variables as captured by Durbin Watson (DW) statistic of 1.77(approximately 2). It shows an unbiased estimate and the model could be used for policy decisions.

\section{Heteroscedasticity Test}

The regression model is homoscedastic as shown in table 6 below:

Table 6: Heteroskedasticity Test- Breusch-Pagan-Godfrey

\begin{tabular}{llll}
\hline \hline F-statistic & 0.040349 & Prob. F(3,23) & 0.9889 \\
Obs*R-squared & 0.141353 & Prob. Chi-Square(3) & 0.9865 \\
Scaled explained SS & 0.106138 & Prob. Chi-Square(3) & 0.9911
\end{tabular}

From table 6, the Prob. F-value gave 0.9889, and it's greater than 0.05; thus we accept the null hypothesis that there is no heteroscedsticity among the variables used in the model

\section{Discussion of Findings}

The findings also showed that seed improvement financing has a significant impact on increased Agricultural production output in Nigeria. Contrary to our findings, Alamu, (2013) results revealed that inadequate funding, delay in release of funds and dearth of manpower is the major challenges facing the implementation of seed improvement financing. They recommended that adequate and timely release of funds for seedling production and provision of $100 \%$ subsidy to enhance cocoa production in the country.

Furthermore, the study revealed that there is a significant relationship between Agricultural production output and increased export earnings in Nigeria. This is contrary to the findings of Akpan, Okon and Udoka, (2014) whose results revealed that, remittances (foreign exchange earnings), agricultural GDP, agricultural productivity index and crop productivity index have positive exponential growth rates, but remittances (foreign exchange earnings) grew at a faster rate than others. It was discovered that, remittance (foreign exchange earnings) has linear and symmetric relationships with agricultural productivity index and crop productivity index in Nigeria. However, there was no significant relationship among growth rates of remittances, agricultural GDP, agricultural productivity index and crop productivity index in Nigeria.

\section{Conclusion and Recommendations}

The study further concludes that, Seed improvement financing has a significant impact on increased Agricultural production output in Nigeria. It showed that about 98.83 percent of the variation in Agricultural production output is explained by Seed improvement financing, while the remaining 1.17 percentage unaccounted variation is captured by the error term. This implies that, Seed improvement financing has strong significant impact on Agricultural production output. Also, the multiplier effect is that, there is a significant relationship between Agricultural production output and increased export earnings in Nigeria. It showed that about 84.47 percent of 
the variation in Agricultural production output is explained by export earnings in Nigeria, while the remaining 15.53 percentage unaccounted variation is captured by the error term. It showed that agricultural production output has strong significant impact on export earnings in Nigeria.

Based on the findings of the study, the following recommendations are here made;

1) Since the findings revealed that Seed improvement financing has a significant impact on increased Agricultural production output in Nigeria, implying that variation in Agricultural production output is based on seed improvement, it is therefore recommended that, there is need for the government to increase funding for agricultural research and also access international grants, as this will help increase variety of high yield seeds, and subsequently increase agricultural production output in Nigeria.

2) Also, since this study has established that there is a significant relationship between Agricultural production output and increased export earnings in Nigeria, it is recommended that for effective diversification of the economy from its present reliance on earnings from oil export, efforts should be made by various stakeholders in the agricultural sector to ensure continuous and sustained technological advancement and seed (input) improvement, as this will ensure higher production output and quality agricultural produce of international standard, to increase foreign earnings as a means of increased government revenue and economic growth.

\section{References}

[1] Abayomi, Y .O (1997), "Agricultural Sector in Nigeria: The Way Forward", The CBN Bullion Vol.21, No.3. July/Sept. 1997.

[2] Adams, W. M., and Mortimore, M.J. (1997). Agricultural Intensification and Flexibility in the Nigerian Sahel. Geographical Journal, 163 (2), 150-160.

[3] Adeniji, O.B. \& Joshua, A.O (2008), "Evaluation of Loan Disbursement and Repayment of Supervised Credit Scheme of Nigeria Agricultural Cooperative and Rural Development Bank(NACRBD) in Zaria and Kaduna North Local Government Areas of Kaduna State, Nigeria," Journal of Agriculture and Social Research (JASR) VOL. 8, No. 2

[4] Adesoye A. B., Maku E. O. \& A. A. Atanda (2011): "Strategic Development Financing Mix and Economic Growth in Nigeria"; Pakistan journal of Social Science 8 (1) 8-12.Agu, C.C. (1998), "Loan management of Agriculture" Readings in Agricultural Finance,

[5] Ed. Martin .O.Ijere and Aja Okorie. Pp119-130 Ahmed, Y. O. (1993), Bank of the North Pamphlets on Agricultural Financing. Various Circulars And Policy Guidelines on Agricultural Financing in Bank of the North Limited. A Paper delivered at Seminars at Bank of the North Human Resources and Development Centre by Agric. Officer, (Bank of the North Limited).

[6] Akpan, S.B. Okon, U.E. \& Udoka, S.J. (2014) Assessment of Empirical Relationships among Remittances and Agricultural Productivity Indicators in Nigeria (1970-2012): American Journal of Economics; 4(1): 52-61

[7] Alamu, S.A. (2013) Analysis of Seedling Subsidy Policy and Cocoa Production in South-West Nigeria; Journal of Educational and Social Research; Vol. 3 (4), pp. 59-68

[8] Alkali, R. (1997). The World Bank and Nigeria: Cornucopia or Pandora Box? Kaduna: Baraka Altenburg, T. (2006). Donor approaches to supporting pro-poor value chains. Donor Committee for Enterprise Development. Working Group on Linkages and Value Chains. http://www.enterprisedevelopment. org/page/linkages-value-chains

[9] Ampratwum, D., A. Dorvlo, O. \& Opara, L. (2004) Usage of tractor and field machinery inagriculture in Oman. Agricultural Engineering International: the CIGR Journal of Scientific Research and Development. Invited Overview Paper. Vol. VI. July 2004 
[10] Ani, A. O. \& Onwualu. A. P. (2002): Agricultural mechanization: A Pre-requisite for foodsecurity in West Africa.. Proc. 1st International Conference of the West African Society of Agricultural Engineering, Abuja, Nigeria. 24-28 Oct. 2002

[11] Anríquez G. \& K. Stamoulis (2007). Rural Development and Poverty Reduction: Is Agriculture Still the Key? ESA Working Paper No. 07-02, Rome Italy, Food and Agricultural Organization.

[12] Asoegwu, S. N. \& Asoegwu, A. O. (2007) An Overview of Agricultural Mechanization and Its Environmental Management in Nigeria”. Agricultural Engineering International: the CIGR Ejournal. Invited Overview, 6(9). May, 2007.

[13] Ayeomoni, O. I. \& Aladejana, S.A. (2016) Agricultural Credit and Economic Growth Nexus.Evidence from Nigeria: International Journal of Academic Research in Accounting, Finance and Management Sciences, 6(2), pp. $146-158$

[14] Bakare, A.S. \& Fawehinmi F.O. (2011) An econometric study of the contribution of oil sector to the standard of living in Nigeria -1975-2008.Asian Journal of Business and Management Sciences Vol. 1 No. 3 [01-08]

[15] Bello O.B. Ganiyu, O.T. Wahab, M.K.A. Afolabi, M.S. Oluleye, F. Ig, S.A. Mahmud, J. \& Abdulmaliq, S.Y. (2012) Evidence of Climate Change Impacts on Agriculture and Food Security in Nigeria: International Journal of Agriculture and Forestry, 2(2): 49-55

[16] Blaug, Mark. (1962). Economic Theory in Retrospect. Second ed. Illinois: Richard D. Irwing, Inc Diao, X., C. Breisinger, S. Kolavalli, E. Quinones and V. Alpuerto (2010).

[17] The Economic Importance of Agriculture for Sustainable Development and Poverty Reduction in Ghana, Case study report contributed to the OECD Global Dowrick, S \& Gemmell, N (1991), "Industrial catching up and economic growth: a comparative study across the world"s capitalist economics" Economic Journal 101:263-276

[18] FMARD (2011) Agricultural Transformation Agenda: We Will Grow Nigeria's Agricultural Sector: Draft for Discussion, Federal Ministry of Agriculture and Rural Development, Abuja, Food and Agricultural Organization. (2006). Rapid Growth of selected Asian Countries.

[19] Lessons and implications for Agricultural and food security synthesis Report. Bangkok: Regional Office for Asia and the Pacific.

[20] Gbaiye, O.G. Ogundipe, A. Osabuohien, E. \& Olugbire, O.O. (2013) Agricultural Exports and Economic Growth in Nigeria (1980 - 2010): Journal of Economics and Sustainable Development; 4(16), pp. 1-5

[21] Isa, M. (2015) Influence of Agricultural Mechanization on Crop Production in Bauchi and Yobe States, Nigeria: A Thesis Submitted to the School of Postgraduate Studies in Partial Fulfillment of the Requirements for the Award of Master of Science Degree in Agricultural Education of the Department of Vocational and Technical Education, Ahmadu Bello University, Zaria

[22] Izekor, O. B. \& Alufolai, G. O. (2010), "Assessment of Cooperative Societies Effectiveness in Agricultural Credit Delivery in IkpobaOkha Local Government Area, Edo State, Nigeria, African Journal of General Agriculture 6(3): 139-143".

[23] Kormawa, P. Okorji, E. \& Okechukwu, R. (2013) Assessment of Seed-Sub Sector Policy in Nigeria; International Institute of Tropical Agriculture.

[24] Lawal, A.A. (1997) "The Economy and the State from the Pre-colonial Times to the Present" in Osuntokun, A. and Olukoju, A. (eds.) Nigerian Peoples and Cultures. Ibadan: Davidson.

[25] Magingxa, L., \& Kamara, A. (2003). Institutional perspectives of enhancing Smallholder Market Access in South Africa, Paper Presented at the 41st Annual Conference of the Agricultural Economic Association of South Africa held in Pretoria.

[26] Mellor, J.W. (1999). Pro-poor growth - the relationship between growth in agriculture and poverty reduction, Paper prepared for USAID. United States Agency for International Development.

[27] Mrema, G. C. \& Odigboh, E. U. (1993): Agricultural development and mechanization in Africa: Policy perspectives. Network for Agricultural Mechanization in Africa (NAMA) Newsletter 1(3): 11-50 
[28] Neill, S. and Lee, D. R. (2001). The Adoption and Disadoption of Sustainable Agriculture. The Case of Cover Crops in Northern Honduras, in Economic Development and Cultural Changes.(ISS. 49, 2001), PP 793-820

[29] Nigerian Educational Research and Development Council, (1991).Nigerian Secondary School Agricultural Project; Agricultural Science for Senior Schools. University Press Plc, Ibadan.

[30] Nzotta, S. M. \& Okereke, E. J. (2009). Financial Deepening and Economic Development of Nigeria: An Empirical Investigation. African Journal of Accounting, Economics, Finance and Banking Research, 5 (5), 55-66.

[31] Obansa, S.A.J. \& Maduekwe, I.M. (2013) Agriculture Financing and Economic Growth in Nigeria: European Scientific Journal; 9(1), pp. 168 - 204

[32] Odozi, V.A. (1995). An Overview of Foreign Investment in Nigeria 1960-1995. Occasional Paper No. 11. Research Department, Central Bank of Nigeria.

[33] Ogen, O (2007), "The Agricultural Sector and Nigeria's Development: Comparative Perspectives from the Brazilian Agro-Industrial Economy, 1960-1995." Nebula 4: 181-194.

[34] Okolo, D. A. (2004), Regional Study on Agricultural Support: Nigeria's Case, being Special Study Report prepared for Food and Agricultural Organization (FAO)

[35] Okumadawa, F. (1997). Poverty and Income in Nigeria: Measurements and Strategies for Reform. A paper presented at the Vision 2010 Workshop, Abuja.

[36] Olomola, A. S. (1997). Agricultural finance. In Philips, A.O., and Tunji-Titilola, S. (eds.) NISER, Olubiyo, S.O. and Hill, G.P. (2002), "Beyond Risk Factor: Bank Lending to Small Scale

[37] Peasant farmers in Nigeria".African Review IssuesOluwaseun, G.G. Ogundipe, A. Osabuohien, E. Olugbire, O.O. Adeniran, A.O. Bolaji-Olutunji, K.A. Awodele, D.O. \& Aduradola, O. (2013) Agricultural Exports and Economic Growth in Nigeria (1980 - 2010): Journal of Economics and Sustainable Development; 4(16), 1-5

[38] Onwualu, A. P. \& Pawa, N.P. (2004). Engineering infrastructure for the manufacture ofagricultural engineering machines in Nigeria: The role of NASENI. Proc. 2ndInternational Conference of the West African Society of Agricultural Engineering,Kumasi, Ghana. 20-24 Sept. 2004.

[39] Ravallion, M. (2000). Growth, Inequality and Poverty: Looking beyond Averages, Development Research Group, ronéo, Banque mondiale, Washington, DC.

[40] Saunders, M. Lewis, P. and Thornhill, A. (2009) Research Methods for Business Students $5^{\text {th }}$ Ed: Prentice Hall Shepherd, A. (2007) "Approaches to linking producers to markets". FAO. Retrieved 25 February 2014.

[41] Taylor, O.H. (1960). A History of Economic Though: Social Ideas and Economic Theories from Quesnay to Keynes. International Student ed. Massachusetts: McGraw HillTiba, Z. (2009). The role of input subsidies: Operational guidelines on implementation. Policies for Good Economic Management of Food Price Swings in African Countries. Rome, FAO Trade and Markets Division.

[42] Uremadu, S.O. \& Onyele, K.O. (2016) the impact of selected agricultural exports on the growth of the domestic economy: Academia Journal of Agricultural Research; 4(5): 281-291.

[43] WAAPP-Nigeria Task Force on Agricultural Seeds (2013) Innovating the Nigerian Agricultural Seeds Sector: A Proposed Action Plan for WAAPP-Nigeria.

[44] World Bank (2008). World Development Report: Agriculture for Development, World Bank.

[45] World Bank (2007). Agriculture for Development, World Development Report 2008, World Bank, Washington DC.

[46] Zhang (2007). "The Financial Deepening-Productivity Nexus in China: 1987-2001", UNU World Institute for Development Economics Research (UNU-WIDER), Research Paper No. 2007/08.

*Corresponding author.

E-mail address: iliyabawa84 @gmail.com 